\title{
PENGARUH MOTIVASI TERHADAP KINERJA PEGAWAI DI SEKRETARIAT DPRD KABUPATEN SIAK
}

\author{
Teguh Hendra \\ Sekolah Tinggi Ilmu Ekonomi Riau \\ E-mail: tehguhhendra19@yahoo.co.id
}

\begin{abstract}
Suatu organisasi pemerintahan dituntut untuk dapat memberikan pelayanan yang baik kepada masyarakat. Dalam hal ini tentu sumber daya manusia yang di miliki organisasi harus menjadi prioritas utama dalam memberikan pelayanan yang baik kepada masyarakat. Maka sumber daya manusia dalam organisasi menjadi salah satu faktor penentu berkembangnya suatu organisasi, karena sumber daya manusia yang dimaksud disini adalah pegawai yang ada dalam organisasi itu sendiri. Untuk dapat memberikan pelayanan yang baik kepada masyarakat, maka motivasi pegawai harus dapat dijaga dan ditingkatkan dengan baik. Secara umum tujuan dari penelitian ini adalah utnuk mengetahui pengaruh motivasi terhadap kinerja pegawai sekretariat DPRD kabupaten siak. Jumlah sampel dalam penelitian ini sebanyak 44 orang pegawai. Pada uji validitas keseluruhan item pernyataan variabel motivasi dan variabel kinerja dinyatakan valid karena diperoleh nilai $\mathrm{r}_{\text {hitung }}>$ $\mathrm{r}_{\text {tabel }}(0.2973)$. Hasil regresi linier sederhana diperoleh nilai $\mathrm{Y}=11.554+0.814 \mathrm{X}$. Dari hasil uji secara parsial atau uji t diperoleh nilai $t_{\text {hitung }}(4.292)>t_{\text {tabel }}(2.01808)$ dengan tingkat sig $0.000<0.05$ yang artinya motivasi berpengaruh signifikan terhadap kinerja. Hasil uji koefisien determinasi $\left(\mathrm{R}^{2}\right)$ sebesar 0.305 atau $30.5 \%$, artinya besarnya pengaruh atau kontribusi yang diberikan oleh variabel motivasi terhadap variabel kinerja sebesar $30.5 \%$ sedangkan sisanya sebesar $69.5 \%$ dipengaruhi oleh faktor lain yang tidak diteliti dalam penelitian ini.
\end{abstract}

Keywords: Motivasi, Kinerja

\section{A. PENDAHULUAN}

Suatu organisasi pemerintahan dituntut untuk dapat memberikan pelayanan yang baik kepada masyarakat. Dalam hal ini tentu sumber daya manusia yang di miliki organisasi harus menjadi prioritas utama dalam memberikan pelayanan yang baik kepada masyarakat. Maka sumber daya manusia dalam organisasi menjadi salah satu faktor penentu berkembangnya suatu organisasi, karena sumber daya manusia yang dimaksud disini adalah pegawai yang ada dalam organisasi itu sendiri. Untuk dapat memberikan pelayanan yang baik kepada masyarakat, maka motivasi pegawai harus dapat dijaga dengan baik. Ada beberapa cara yang dapat dilakukan agar dalam bekerja para pegawai termotivasi untuk mampu menyelesaikan pekerjaannya dengan baik misalnya seperti memperhatikan kesejahteraan para pegawai, memberikan fasilitas atau peralatan kerja yang memadai dan sesuai dengan aktifitas kerja pegawai, dan lain sebagainya. Ini dilakukan agar motivasi pegawai dalam bekerja dapat terjaga dengan baik. Motivasi kalau tidak dijaga dengan baik akan berimbas pada hasil pekerjaan seseorang dalam organisasi tersebut, karena setiap pekerjaan yang dilakukan kurang maksimal dikarenakan rendahnya atau turunnya motivasi seseorang dalam menyelesaikan pekerjaannya. Sekretariat DPRD kabupaten siak memiliki visi mewujudkan tata kelola kepemerintahan yang baik, bersih, serta pelayanan publik yang prima. Untuk mewujudkan visinya dengan baik, tentu harus didukung dengan motivasi pegawai yang baik untuk dapat mewujudkannya. Berikut gambaran jumlah pegawai yang ada pada sekretariat DPRD kabupaten siak.

Tabel. 1. Data jumlah pegawai sekretariat DPRD kabupaten siak

\begin{tabular}{|c|c|c|}
\hline Tahun & $\begin{array}{c}\text { Jumlah } \\
\text { Pegawai }\end{array}$ & $\begin{array}{c}\text { Persentase } \\
\text { perkembangan } \\
\text { jumlah pegawai }\end{array}$ \\
\hline 2014 & 55 & - \\
\hline 2015 & 57 & $3.63 \%$ \\
\hline 2016 & 56 & $-1.75 \%$ \\
\hline 2017 & 52 & $-7.14 \%$ \\
\hline 2018 & 44 & $-15.38 \%$ \\
\hline
\end{tabular}

Sumber : Sekretariat DPRD kabupaten siak, 2019

Dari tabel 1 dapat dilihat jumlah pegawai sekretariat DPRD kabupaten siak pada tahun 2014 berjumlah 55 orang, dan bertambah menjadi 57 orang atau naik sebesar $3.63 \%$, pada tahun 2016 berkurang sebesar $-1.75 \%$ atau menjadi 56 orang pegawai, dan kembali berkurang pada tahun 2017 dan tahun 2018 menjadi darai 52 orang berkurang kembali menjadi 44 orang 
atau turun sebesar $-15.38 \%$ pada tahun 2018 pada sekretariat DPRD kabupaten siak.

Berikut gambaran yang ditemui dari hasil observasi dan wawancara yang dilakukan peneliti terhadap pegawai yang berhubungan dengan motivasi kerja para pegawai pada sekretariat DPRD kabupaten siak diantaranya :

1. Peralatan kerja yang ada kurang mendukung dalam melaksanakan pekerjaan.

2. Fasilitas yang ada masih belum memenuhi standar kelayakan yang berdampak terhadap kinerja para pegawai.

3. Kurangnya

kegiatan-kegiatan pengembangan sumber daya manusia khususnya mengenai peningkatan kualitas kemampuan pegawai melalui kegiatan pelatihan.

4. masih dijumpai pegawai yang datang terlambat dan pulang cepat di jam kerja yang telah ditetapkan.

5. Beberapa kegiatan yang telah diprogramkan atau direncanakan masih ada yang belum maksimal dalam penyelesaiannya sehingga menyebabkan lambatnya penyelesaian kegiatan yang telah diprogramkan setiap tahunnya.

Selain data jumlah pegawai diatas berikut gambaran hasil capaian kerja pegawai yang dilihat dari SKP (sasaran capaian kerja) pada sekretariat DPRD kabupaten siak.

Tabel. 2. Data Penilaian Sasaran Kerja Pegawai (SKP) Pada Sekretariat DPRD

Kabupaten Siak tahun 2014 - 2018

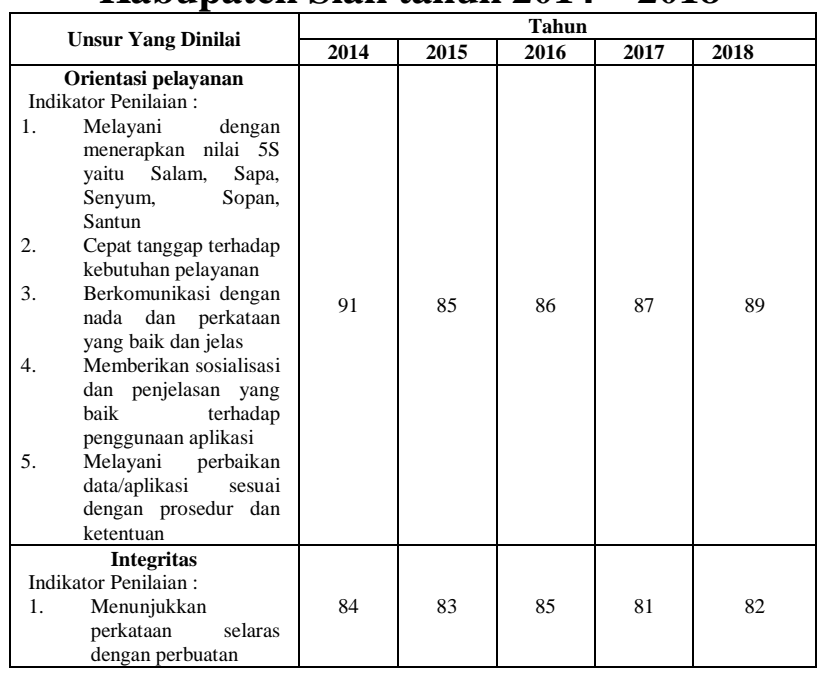

Eko dan Bisnis (Riau Economics and Business Reviewe) Volume 10, Nomor 4, 27 Desember 2019

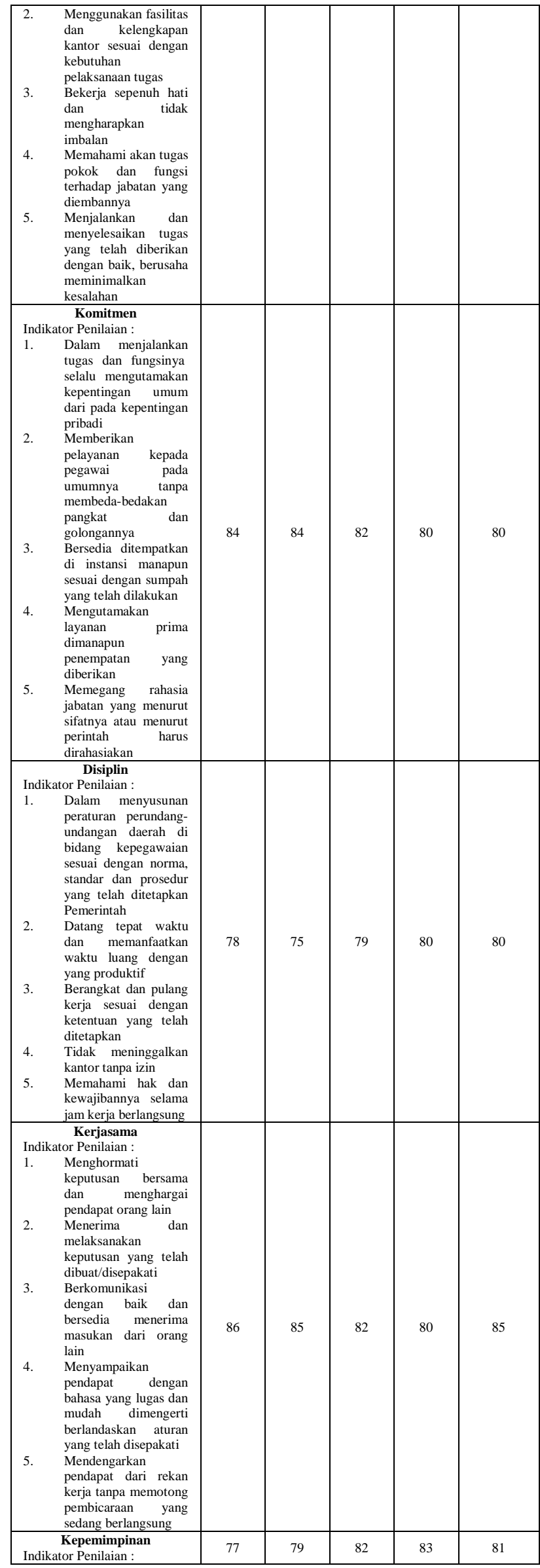

P.ISSN: $1410-7988$
E.ISSN: 2614-123X 


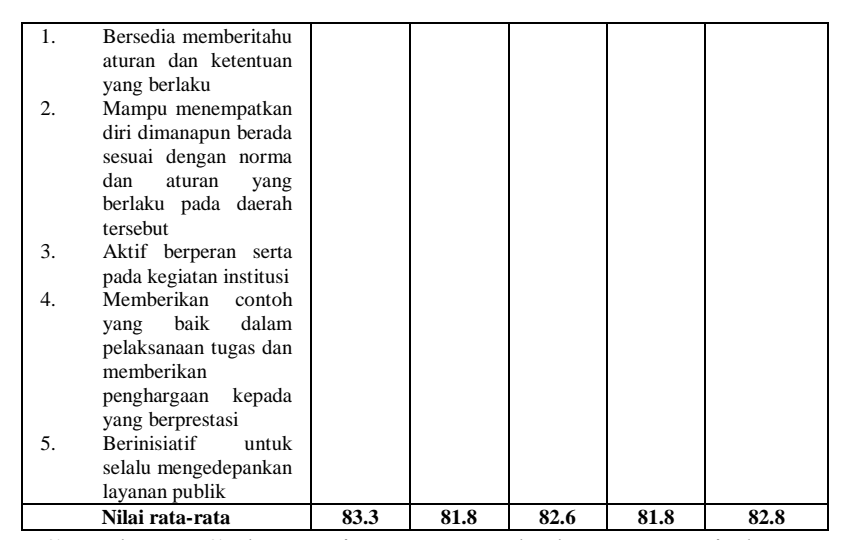

Sumber : Sekretariat DPRD kabupaten siak, 2019

Berdasarkan data dari tabel 2 diatas terkait Penilaian Sasaran Kerja Pegawai (SKP), terlihat secara garis besar bahwa dari tahun 2014 - 2018 SKP pegawai berfluktuasi, seperti pada tahun 2014 nilai rata-rata SKP pegawai sebesar 83.3. Di tahun 2015 nilai rata-rata SKP pegawai menurun menjadi 81.8. Tahun 2016 nilai rata-rata SKP pegawai peningkat menjadi 82.6. Namun pada tahun 2017 nilai rata-rata SKP pegawai terjadi penurunan menjadi 81.8. Pada tahun 2018 nilai rata-rata SKP Pegawai adalah 82.8. Berikut tabel pengukuran kinerja selama 5 (lima) tahun periode 2014 - 2018 di Sekretariat DPRD Kabupaten Siak.

Berikut rekapitulasi capaian kerja pegawai pada sekretariat DPRD Kabupaten Siak tahun 2014-2018

\section{Tabel 3. Data Rekapitulasi Pengukuran Kinerja Pegawai Sekretariat DPRD Kabupaten Siak Tahun 2014-2018}

\begin{tabular}{|c|c|c|c|c|c|c|}
\hline \multirow{2}{*}{ No } & \multirow{2}{*}{ Keterangan } & \multicolumn{5}{|c|}{ Persentase Realisasi Per Tahun } \\
\hline & & 2014 & 2015 & 2016 & 2017 & 2018 \\
\hline 1 & $\begin{array}{c}\text { Bagian Umum } \\
\text { (30 Kegiatan) } \\
\text { Indikator : } \\
\text { Tingkat kepuasan layanan kegiatan } \\
\text { administrasi perkantoran }\end{array}$ & $82 \%$ & $80 \%$ & $81 \%$ & $83 \%$ & $84 \%$ \\
\hline 2 & $\begin{array}{c}\text { Bagian Risalah } \\
\text { (5 kegiatan) } \\
\text { Indikator : } \\
\text { Kegiatan Reses, hearing dan } \\
\text { paripuma yang dilaksanakan sesuai } \\
\text { dengan jadwal badan musyawarah }\end{array}$ & $79 \%$ & $83 \%$ & $80 \%$ & $82 \%$ & $85 \%$ \\
\hline 3 & $\begin{array}{c}\text { Bagian Keuangan } \\
\text { (5 Kegiatan) } \\
\text { Indikator : } \\
\text { Tingkat Kepuasan DPRD terhadap } \\
\text { pelayanan kegiatan administrasi } \\
\text { keuangan }\end{array}$ & $82 \%$ & $84 \%$ & $84 \%$ & $85 \%$ & $86 \%$ \\
\hline
\end{tabular}

Sumber : Sekretariat DPRD kabupaten siak, 2019

Dari tabel 3 dapat dijelaskan bahawa capaian kerja pegawai tahun 2014 sampai

Eko dan Bisnis (Riau Economics and Business Reviewe) Volume 10, Nomor 4, 27 Desember 2019 tahun 2018 pada tiap bagian yang ada pada secretariat DPRD Kabupaten Siak masih belum maksimal. Hal in I dikarenakan capaian masing-masing bagian belum menyentuh angka $100 \%$. Maka berdasarkan tabel 3 diatas dapat disimpulkan bahwa kinerja pegawai sekretariat DPRD Kabupaten Siak masih belum maksimal. Padahal sudah dirancang beberapa program-program kegiatan yang akan dilaksanakan pada tiap tahunnya, dengan pencapaian ini tentu ada beberapa kegiatan belum dapat terlaksana dengan baik.

Berdasarkan fenomena dan latar belakang diatas, maka saya tertarik melakukan penelitian pada dinas perikanan dan kelautan kabupaten Pelalawan dengan judul "Pengaruh Motivasi Terhadap Kinerja Pegawai di Sekretariat DPRD Kabupaten Siak" Manajemen Sumber Daya Manusia

Supomo (2018: 4) manajemen sumber daya manusia adalah ilmu dan seni yang mengatur peranan tenaga kerja ( $m a n$ ) yang terdapat pada organisasi agar efektif dan efisien demi terwujudnya suatu tujuan.

Hasibuan (2018: 10) manajemen sumber daya manusia adalah ilmu dan seni mengatur hubungan dan peranan tenaga kerja agar efektif dan efisien membantu terwujudnya tujuan perusahaan, karyawan, dan masyarakat.

Kasmir (2016: 6) secara sederhana mengartikan manajemen sumber daya manusia adalah proses pengelolaan manusia, melalui perencanaan, rekrutmen, seleksi, pelatihan, pengembangan, pemberian kompensasi, karier, keselamatan dan kesehatan serta menjaga hubungan industrial sampai pemutusan hubungan kerja guna mencapai tujuan perusahaan dan peningkatan kesejahteraan stakeholder.

\section{MOTIVASI \\ Pengertian Motivasi}

Motivasi atau motif berasal dari bahasa latin yaitu "moreve" yang berarti dorongan dari dalam diri manusia untuk 
bertindak atau berperilaku. Menurut Notoatmodjo (2009: 115) motivasi adalah suatu alasan seseorang untuk bertindak dalam rangka memenuhi kebutuhan hidupnya.

Menurut Widodo (2015:

motivasi adalah kekuatan yang ada dalam seseorang, yang mendorong perilakunya untuk melakukan tindakan.

Menurut Robbins (2006) dalam Priansa (2016: 201) menyatakan bahwa motivasi adalah proses yang menunjukkan intensitas individu, arah, dan ketekunan dari upaya menuju pencapaian tujuan.

\section{Teknik Motivasi Karyawan}

Mangkunegara (2013: 101) ada beberapa teknikmemotivasi kinerja karyawan, antara lain sebagai berikut :

1. Teknik pemenuhan kebutuhan karyawan. Pemenuhan kebutuhan karyawan merupakan fundamen yang mendasari perilaku kerja. Kita tidak mungkin dapat memotivasi kerja karyawan tanpa memperhatikan apa yang dibutuhkannya.

2. Teknik komunikasi persuasif

Merupakan salah satu teknik memotivasi kerja karyawan yang dilakukan dengan cara mempengaruhi karyawan secara ekstralogis, teknik ini dirumuskan "AIDDAS"
A = Attention (perhatian)
I $\quad=$ Interest (minat)
$\mathrm{D} \quad=$ Desire (hasrat)
D $\quad=$ Decision (keputusan)
A $\quad=$ Action (aksi/ tindakan)
$\mathrm{S} \quad=$ Satisfaction (kepuasan)

\section{Indikator Motivasi}

Edison, Anwar, dan Komariyah (2016: 184) mengembangkan teori kebutuhan Abraham Maslow sebagai dimensi atau indikator dari motivasi, yaitu :

1. Kebutuhan fsiologis.

2. Kebutuhan rasa aman.

3. Kebutuhan untuk disukai.

4. Kebutuhan harga diri.

5. Kebutuhan pengembangan diri.

\section{KINERJA}

\section{Pengertian Kinerja}

Kinerja seseorang merupakan kombinasi dari kemampuan, usaha dan kesempatan yang dapat dinilai dari hasil kerjanya. Secara defenitif menurut Bernadin \& Russell menjelaskan kinerja merupakan catatan outcome yang dihasilkan dari fungsi pegawai tertentu atau kegiatan yang dilakukan selama periode waktu tertentu, (Sulistiyani dan Rosidah, 2018: 111).

Kinerja merupakan performance atau unjuk kerja. Kinerja dapat pula diartikan sebagai prestasi kerja atau pelaksanaan kerja atau hasil kerja unjuk kerja. Smith menyatakan bahwa kinerja merupakan hasil dari suatu proses yang dilakukan manusia, (Suwatno dan Priansa, 2018: 196).

Edison, Anwar, dan Komariyah (2016: 190) kinerja adalah hasil dari suatu proses yang mengacu dan diukur selama periode waktu tertentu berdasarkan ketentuan atau kesepakatan yang telah ditetapkan sebelumnya.

\section{Penilaian Kinerja}

Menurut Dessler, Gary dalam Sedarmayanti (2017: 284) penilaian kinerja adalah prosedur apa saja yang meliputi :

1. Penetapan standar kinerja.

2. Penilaian kinerja actual karyawan dalam hubungan dengan standar.

3. Member umpan balik kepada karyawan dengan tujuan memotivasi karyawan untuk menghilangkan penurunan kinerja atau terus bekerja lebih giat.

Menurut Davis dalam Kasmir (2016: 185) penilaian kinerja merupakan suatu proses dimana organisasi mengevaluasi hasil kinerja individu karyawan.

Busro, (2018: 95) penilaian kinerja (performance appraisal) adalah suatu cara yang dilakukan untuk menilai prestasi kerja seorang pegawai apakah mencapai target pekerjaan yang dibebankan kepadanya. 


\section{Indikator Kinerja}

Sesuai dengan Peraturan Kepala Badan Kepegawaian Negara Nomor 1 tahun 2013 tentang ketentuan pelaksanaan peraturan pemerintah nomor 46 tahun 2011 tentang penilaian prestasi kerja pegawai negeri sipil, maka yang menjadi indikator kinerja pegawai adalah sebagai berikut :

1. Orientasi pelayanan. Merupakan sikap dan perilaku kerja pegawai dalam memberikan pelayanan kepada masyarakat, atasan, rekan sekerja, unit kerja terkait, dan/atau instansi lain.

2. Integritas. Merupakan kemampuan seorang pegawai untuk bertindak sesuai dengan nilai, norma dan etika dalam organisasi.

3. Komitmen. Merupakan kemauan dan kemampuan seorang pegawai untuk dapat menyeimbangkan antara sikap dan tindakan untuk mewujudkan tujuan organisasi dengan mengutamakan kepentingan dinas daripada kepentingan diri sendiri, seseorang, dan/atau golongan.

4. Disiplin. Merupakan kesanggupan seorang pegawai untuk menaati kewajiban dan menghindari larangan yang ditentukan dalam peraturan perundang-undangan atau peraturan kedinasan yang apabila tidak ditaati atau dilanggar dijatuhi sanksi.

5. Kerja sama. Merupakan kemauan dan kemampuan seorang pegawai untuk bekerja sama dengan rekan sekerja, atasan, bawahan baik dalam unit kerjanya maupun instansi lain dalam menyelesaikan suatu tugas dan tanggung jawab yang diembannya.

6. Kepemimpinan.

Merupakan kemampuan dan kemauan pegawai untuk memotivasi dan mempengaruhi bawahan atau orang lain yang berkaitan dengan bidang tugasnya demi tercapainya tujuan organisasi.

Eko dan Bisnis (Riau Economics and Business Reviewe) Volume 10, Nomor 4, 27 Desember 2019

\section{Pengaruh Motivasi Terhadap Kinerja}

Priansa (2016: 270) kinerja dipengaruhi oleh faktor kemampuan (ability) dan faktor motivasi (motivation).

Edison, Anwar, dan Komariyah (2016: 181) melalui pengembangan hierarki kebutuhan, atau dengan meningkatkan kebutuhan karyawan pada tingkat yang lebih tinggi, dapat memotivasi karyawan dan menciptakan iklim kerja yang menyenangkan, pada gilirannya meningkatkan kinerja yang lebih baik.

\section{HIPOTESIS}

Hipotesis adalah sebagai jawaban sementara terhadap rumusan masalah penelitian. Rumusan masalah tersebut bisa berupa pernyataan tentang hubungan dua variabel atau lebih, perbandingan (komparasi), atau variabel mandiri (deskripsi), (Sugiyono, 2019: 84). Berdasarkan pada perumusan masalah dan tujuan penelitian penulis mengajukan hipotesis adalah diduga motivasi berpengaruh signifikan terhadap kinerja pegawai di Sekretariat DPRD Kabupaten Siak.

\section{METODE}

\section{Lokasi Penelitian}

Penelitian ini dilaksanakan di Sekretariat DPRD Kabupaten Siak yang bertempat di Jl. Panglima Ghimbam No. 2, Kampung. Rempak, Kabupaten Siak, Provinsi Riau.

\section{Jenis Dan Sumber Data}

Sujarweni (2014: 73) sumber data adalah subjek dari mana asal data penelitian itu diperoleh. Berdasarkan sumbernya data dibagi menjadi :

\section{Data Primer.}

Data primer adalah data yang diperoleh dari responden melalui kuesioner, kelompok fokus, dan panel, atau juga data hasil wawancara peneliti dengan nara sumber. Data yang diperoleh dari data primer ini harus diolah lagi. 


\section{Data Skunder.}

Data skunder yaitu data yang didapat dari catatan, buku, majalah berupa laporan keuangan publikasi perusahaan, laporan pemerintah, artikel, buku-buku sebagai teori, majalah dan lain sebagainya.

\section{Populasi Dan Sampel \\ Populasi}

Sugiyono (2016: 80) populasi adalah wilayah generalisasi yang terdiri atas objek/ subjek yang mempunyai kualitas dan karakteristik tertentu yang ditetapkan oleh peneliti untuk dipelajari kemudian ditarik kesimpulannya. Populasi dalam penelitian ini adalah seluruh sekretariat DPRD kabupaten siak yang berjumlah sebanyak 44 orang.

\section{Sampel}

Menurut Sugiyono (2016: 81), sampel adalah bagian dari jumlah dan karakteristik yang dimiliki oleh populasi tersebut, dikarenakan populasi kecil maka seluruh populasi dijadikan sampel. Maka sampel yang digunakan dalam penelitian ini berjumlah 44 orang pegawai sekretariat DPRD kabupaten siak, dengan teknik pengambilan sampel dengan menggunakan sampling jenuh yaitu teknik penentuan sampel bila semua anggota populasi dijadikan sampel atau istilah lain sampel jenuh adalah sensus, dimana semua anggota populasi dijadikan sampel.

\section{Analisis Data}

Metode penelitian yang digunakan pada penelitian ini adalah dengan metode kuantitatif. Dimana uji kuantitatif merupakan metode kuantitatif dapat diartikan sebagai metode penelitian yang berlandaskan pada filsafat positivisme, digunakan untuk meneliti pada populasi atau sampel tertentu, pengumpulan data menggunakan instrumen penelitian, analisis data bersifat kuantitaif/ statistik, dengan tujuan untuk menguji hipotesis yang ditetapakan (Sugiyono, 2015).

Dalam metode analisis data, peneliti menggunakan regresi linier sederhana. Sujarweni (2015: 111) regresi yang memiliki satu variable dependen dan satu variabel Volume 10, Nomor 4, 27 Desember 2019 independent. Model persamaan regresi linier sederhana dengan rumus sebagai berikut :

$\mathrm{Y}=\mathrm{a}+\mathrm{bX}$

Dimana :

$\mathrm{Y} \quad=$ Kinerja (Subyek dalam variabel dependen yang diprediksi)

a $=$ Konstanta (Harga Y ketika harga $\mathrm{X}=0$ atau konstant)

$\mathrm{b} \quad=$ Angka arah koefisien regresi

$\mathrm{X}=$ Motivasi (Subyek pada variabel independen yang mempunyai nilai tertentu).

\section{HASIL}

Berdasarkan hasil uji validitas yang dilakukan, seluruh item penyataan dalam penelitian ini dinyatakan valid dimana nilai

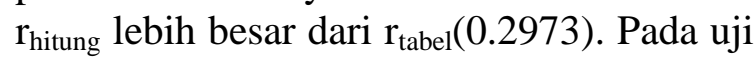
reliabilitas, variabel dalam penelitian ini dinyatakan reliabel atau layak, dimana hasil pengujian melalui SPSS diperoleh hasil cronbach's alpha pada variabel motivasi (0.771) dan variabel kinerja (0.913) lebih besar dari 0.6. Dan berdasarkan uji normalitas, dapat dinyatakan bahwa sebaran data yang mendekati garis diagonal maka sebaran data memenuhi asumsi normalitas. Sehingga dapat disimpulkan bahwa data jawaban responden sudah berdistribusi normal.

Hasil pengolahan regresi linier sederhana dengan menggunakan SPSS diperoleh hasil regresi linier sebagai berikut:

\section{Tabel 4}

Uji Regresi Linier Sederhana

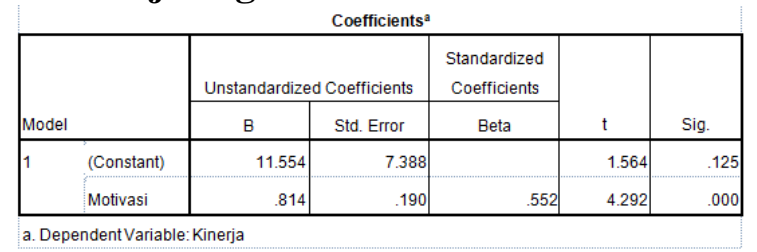

Sumber : Data olahan hasil penelitian, 2019

Berdasarkan hasil dari pengolahan data yang disajikan pada tabel 4 diatas, maka didapat persamaan regresi linier sederhana sebagai berikut :

$\mathrm{Y}=\mathrm{a}+\mathrm{bX}$, dimana

$\mathrm{Y}=11.554+0.814 \mathrm{X}$ 
Persamaan regresi tersebut dapat dijelaskan sebagai berikut :

Nilai konstanta (a) $=11.554$ ini menyatakan bahwa variabel motivasi (X) dianggap konstan maka kinerja (Y) adalah sebesar 0.814. Artinya jika nilai motivasi mengalami kenaikan 1 satuan, maka nilai kinerja akan mengalami kenaikan sebesar 0.814 . Koefisien bernilai positif, artinya terjadi pengaruh yang positif antara motivasi terhadap kinerja jika semakin besar nilai motivasi maka semakin meningkat nilai kinerja.

\section{Uji Hipotesis}

\section{Uji t}

Berdasarkan hasil olahan SPSS pada tabel 4 diatas dapat dijelaskan bahwa dikarenakan nilai $t_{\text {hitung }}$ (4.292) lebih besar dari nilai $t_{\text {tabel }}$ (2.01808) maka dapat disimpulkan bahwa Ho ditolak dan $\mathrm{Ha}$ diterima dengan tingkat signifikan $0.000<$ 0.005 , yang artinya terdapat pengaruh positif dan signifikan antara variabel motivasi terhadap variabel kinerja.

\section{Koefisien Determinasi $\left(\mathbf{R}^{2}\right)$}

Untuk mengetahui besar pengaruh variabel independen terhadap variabel dependent maka dilakukan uji koefisien determinasi (R2). Berikut hasil uji koefisien determinasi dapat dilihat pada tabel dibawah ini :

Tabel 5. Koefisien determinasi $\left(\mathbf{R}^{2}\right)$

\begin{tabular}{|l|r|r|r|r|}
\hline Model & \multicolumn{1}{|c|}{ Rodel Summary } \\
\hline 1 & $.552^{3}$ & R Square & $\begin{array}{c}\text { Adjusted R } \\
\text { Square }\end{array}$ & $\begin{array}{c}\text { Std. Error of the } \\
\text { Estimate }\end{array}$ \\
\hline \multicolumn{2}{|l|}{ a. Predictors: (Constant), Motivasi } \\
b. Dependent Variable: Kinerja
\end{tabular}

Sumber : Data olahan hasil penelitian, 2019

Dari tabel 5 dapat dilihat bahwa nilai koefisien determinasi $\left(\mathrm{R}^{2}\right)$ sebesar 0.305 artinya sumbangan atau kontribusi besarnya pengaruh variabel motivasi terhadap variabel kinerja sebesar 0.305 atau $30.5 \%$ sedangkan sisanya $(100-30.5)=69.5 \%$ dipengaruhi oleh variabel lain yang diabaikan atau tidak diteliti dalam penelitian ini.

\section{SIMPULAN}

Dari hasil uji kuantitatif malalui uji regresi yang telah dilakukan, pada Uji $\mathrm{t}$ dapat dijelaskan bahwa secara parsial motivasi berpengaruh positif dan signifikan terhadap kinerja pegawai Sekretariat DPRD Kabupaten Siak. Besarnya pengaruh ataupun kontribusi variabel motivasi terhadap kinerja sebesar $30.5 \%$.

\section{DAFTAR RUJUKAN}

Busro, Muhammad, 2018, Teori-Teori Manajemen Sumber Daya Manusia, Edisi Pertama, Cetakan Ke-1, Prenadamedia Group, Jakarta.

Edison, Emron, Anwar, Yohny, dan Komariyah, Imas, 2016, Manajemen Sumber Daya Manusia : Strategi dan Perubahan Dalam Rangka Meningkatkan Kinerja Pegawai dan Organisasi, Cetakan Kesatu, CV. Alfabeta, Bandung.

Hasibuan, Malayu S. P, 2018, Manajemen Sumber Daya Manusia, Edisi Revisi, PT. Bumi Aksa: Jakarta.

Kasmir, 2016, Manajemen Sumber Daya Manusia (Teori dan Praktik), Ed.1Cet.2, Rajawali Pers, Jakarta.

Mangkunegara, A.A.Anwar Prabu, 2013, Manajemen Sumber Daya Manusia Perusahaan, cetakan kesebelas, PT. Remaja Rosdakarya, Bandung.

Notoatmodjo, $\quad$ Soekidjo, 2009, Pengembangan Sumber Daya Manusia, Penerbit. Rineka Cipta. Jakarta.

Priansa, Juni, Donni, 2016, Perencanaan \& Pengembangan SDM, cetakan kedua, Alfabeta, Bandung.

Sulistiyani, Ambar Teguh, dan Rosidah, 2018, Manajemen Sumber Daya Manusia Pendekatan Teoretik dan praktik Untuk Organisasi Publik, Cetakan I, Gava Media, Yogyakarta.

Suwatno, dan Priansa, Donni Juni, 2018, Manajemen SDM Dalam Organisasi Publik dan Bisnis, Cetakan Keenam, Alfabeta, Bandung. 
Sedarmayanti, 2017, Manajemen Sumber

Daya Manusia (Reformasi Birokrasi dan

Manajemen Pegawai Negeri Sipil), Edisi

Revisi, Cetakan Kesembilan, PT. Refika

Aditama, Bandung.

Sugiyono, 2019, Statistika Untuk Penelitian, cetakan ke-30, Alfabeta, Bandung.

Sujarweni, Wiratna.V. 2014, Metodologi

Penelitian, Pustakabarupress. Cet.1. Yogyakarta.

Sugiyono, 2016, Metode Penelitian Kuantitatif, Kualitatif, dan $R \& D$, Cetakan Ke-23, Alfabeta, Bandung.

Sugiyono, 2008, Memahami Penelitian Kualitatif. CV. Alfabeta. Bandung.

Sugiyono. (2015). Metode penelitian Kuantitatif, kualitatif dan R\&D Cetakan ke-20. Bandung: Penerbit Alfabeta Komputindo.

Sujarweni, V Wiratna, 2015, Statistik Untuk Bisnis \& Ekonomi, Pustaka baru press, Yogyakarta.

Supomo. R, 2018, Pengantar Manajemen, Cetakan I, Yrama Widya, Bandung.

Widodo, Suparno, Eko, 2015, Manajemen Pengembangan Sumber Daya Manusia, Cetakan II, Pustaka Pelajar, Yogyakarta. 